2018 $\begin{array}{r}\text { 2018 Volume 24(2): 335-357 } \\ \text { doi:10.3846/20294913.2016.1212744 }\end{array}$

\title{
NEW AGGREGATION OPERATORS FOR DECISION-MAKING UNDER UNCERTAINTY: AN APPLICATIONS IN SELECTION OF ENTREPRENEURIAL OPPORTUNITIES
}

\author{
Fabio BLANCO-MESA ${ }^{\mathrm{a}, \mathrm{c}}$, Anna María GIL-LAFUENTEa, José M. MERIGÓb \\ ${ }^{a}$ Department of Economics and Business Administration, Faculty of Economics and Business, \\ University of Barcelona, Av. Diagonal, 690, 08034, Barcelona, Spain \\ ${ }^{b}$ Department of Management Control and Information Systems, School of Economic and Business, \\ University of Chile, Av. Diagonal Paraguay, 257, 8330015, Santiago, Chile \\ ${ }^{c}$ Department of Economic and Administrative Sciences, School of Business Administration, Pedagogical \\ and Technological University of Colombia, North Central Avenue 39-115, 150001,Tunja, Boyacá-Colombia
}

Received 11 March 2015; accepted 25 November 2015

\begin{abstract}
The main aim of this paper is to study how economic environment and logic reasoning guidance the decision-making process to start-up a new business by potential entrepreneurs. The study proposes a new method using the family of selection indices with OWA operator, which allows aggregating information according to the level of importance and their level of objectivity and subjectivity in the same formulation within the decision-making process. To develop case study, we have taken into account some industries of the sports sector and some critical environmental factors that influence the competitiveness and entrepreneurship in Colombia to start a new business. The results show in an orderly way all information aggregated, which can help potential investors and entrepreneurs to make a decision based on their preferences. Finally, the applicability of this method in real case can be given in aggregation different sources of information to help at dealing decision-making processes.
\end{abstract}

Keywords: decision-making process, fuzzy weighted, OWA and selection indices, entrepreneurial opportunities, new business.

JEL Classification: C44, C60, M13, L26.

\section{Introduction}

Currently, entrepreneurship is a fundamental referent to the economic development for a region or a nation, because it is considered as an engine of change, innovation and economic growth (Audretsch, Peña-Legazkue 2012; Praag, Versloot 2007). Entrepreneurship, as fundamental factor within the economic development, has awake the interest of policy-

Corresponding author Fabio Blanco-Mesa

E-mails: frblamco@gmail.com, fabio.blanco01@uptc.edu.co 
makers and the academic community to study the factors that influence entrepreneur as an agent of change, and entrepreneurship as the process of the change (Audretsch, Keilbach 2004; Acs, Amorós 2008). Both elements are linked directly to competitiveness and its impact on the economy and are used to assessing the level of entrepreneurial activity (Carree, Thurik 2010). However, the impact of entrepreneurship on an economy depends on two elements, the stage of development of each country (van Stel et al. 2005) in accordance with their environmental conditions. Thus, it is noteworthy that entrepreneurship has a crucial role to play within economic and social environment. Environmental factors have relevant influence on the level of entrepreneurial activity because they cause different degrees of uncertainty that affect the determinants of entrepreneurship (Verheul et al. 2002). Potential entrepreneurs use their intuition and knowledge to perceive these factors, which condition their decision to be employed or not. Indeed, the information provided from the environment is used by the entrepreneur to form a positive or negative attitude, i.e. an attitude toward a degree of pessimism or optimism (Merigó 2009; Merigó et al. 2014; Merigó, Peris-Ortiz 2014).

The main aim of this paper is to study how economic environment and logic reasoning guidance the decision-making process to start-up a new business by potential entrepreneurs. Hence, we have proposed a new method using the family of selection indices with OWA operator (see Merigó 2009). This new method allows aggregating information according to the level of importance and their level of objectivity and subjectivity in the same formulation within the decision-making process. To develop mathematical application, we have used resulting data of competitiveness report and GEM report, which are focused on Colombia. Likewise, we have used as sector example six industries of the sports sector, which are considered as potential industries to star an entrepreneurial activity. According to Miller et al. (2014) Colombia is considered as one of the South American economies with better levels of macroeconomic stability for foreign investment. Furthermore, Colombia's competitiveness is on the efficiency-drive stage, which has a less positive impact on their entrepreneurial activity. In fact, Colombia produce goods and services with discreet value added and less innovative, which is characteristic of a managed economy, (Acs, Amorós 2008). On the other hand, sports sector, in Colombia, offers an opportunity to promote entrepreneurial activities, since the current sports environment generates new welfare needs, which stimulates the demand of sports goods and services. Thus, the dynamic of the sports sector promotes the creation of new sports businesses, which are able to offer new forms of consumption of services and sporting goods that fit the aspirations of its customers (Heinemann 1994).

This paper is structured as follows: firstly, we presents theoretical framework, which is composed by a briefly review of entrepreneurship from economy view and the main contribution of the OWA operators in the decision-making process on business. Secondly, we develop a case study based on the reports of competitiveness and entrepreneurship of Colombia, as well as a briefly description of the sports sector to carry out the application of the method designed. Thirdly, we define methodology, variables and mathematical model. Fourthly, we explain the application of the method and the main results. Finally, we present the conclusion and implications of the research. 


\section{Theoretical framework}

\subsection{Entrepreneurship for economic development}

The economic crisis in development Western countries has made the competitiveness and entrepreneurship fundamental strategic axes that encourage and lead an economy. Competitiveness is defined by multiple factors, policies and institutions groups, which describe the economic environment the level of prosperity within a nation. Moreover, entrepreneurship contributes to economic development because it encourages job creation innovation, productivity and growth (Praag, Versloot 2007; Wennekers et al. 2005). In recent years, some researches have been directed to study the relationship between entrepreneurship and competitiveness (van Stel et al. 2005; Audretsch 2009; Carree, Thurik 2010; Audretsch, Peña-Legazkue 2012; Casero et al. 2013). Also, they have conducted studies that focus on the relationship between entrepreneurship and performance where the company is studied as a unit within a geographic region (Carree, Thurik 2010).

According to Carree and Thurik (2010) that entrepreneurship effects over economy are spread into four main strands across the country, such as, regional, industry, country and entrepreneurial activity level. At the regional level, these effects are concentrated on the size distribution in regions. At the industry level, they are focused on the share of market participation in an industry, aspect that can have an influence on the increase in the number of competitors. At the country level, effects are focused on the number of self-employment and entrepreneurial intention. These aspects are related to a higher level, intensive and extent of the entrepreneurial activity. Finally, the last approach assesses the level of national entrepreneurial activity, which is related to the rate of economic growth. Nevertheless, the impact of entrepreneurship on economy changes among countries and their different stages of economic development (van Stel et al. 2005). In fact, economic development has an indirect influence on determinants of entrepreneurship either on decision making process of individual, or on market specific or range of environmental factors (Verheul et al. 2002).

Globally, the competitiveness of countries is assessed through the global competitiveness index (GCI), which allows determining their stage of development (WEF 2002) and governments across the world agree this index widely. This index classifies the stage of development in three main factors (Factor-Drive; Efficiency-Drive; Innovation-Drive) and twostep transition. These factors are determined by the evaluation of the interrelation of the 12 pillars of competitiveness (WEF 2014). Competitiveness' analysis allows understanding the microeconomic and macroeconomic context within the social and the environmental dimension (Sala i Martín et al. 2014). According to Verheul et al. (2002) this analysis provides descriptive information about economic characteristics of the environment that could impact on the creation of entrepreneurial opportunities. Furthermore, competitiveness' analysis also allows comprehending the new view of the economic development, which has evolved from a notion of the economy of accumulation to a notion of the economy of knowledge (Wennekers et al. 2005). In fact, this aspect are linked to the evolution from the management economy to entrepreneurial economy (Audretsch, Thurik 2001). In this process, the change stage of development represents the evolutionary change of economic 
development of a nation. These changes range from low cost production efficiency, efficient productive practices to exploit economies of scale to finally become a knowledge-based economy. Likewise, these change also influence the level of entrepreneurship because they can change push and pull factors within the labour market and product markets (Verheul et al. 2002). In fact, the best agent for this change is the entrepreneur (Acs, Amorós 2008) and the entrepreneurial activity is the process of the change (Audretsch, Keilbach 2004). These changes are highlighted because they reflect a more dynamic economic system.

Another important aspect is the economic performance of entrepreneurial activity because it is a key factor that promotes the introduction of innovation, enhances rivalry, creates competition and takes advantage of the new gaps within the market (Wong et al. 2005). Indeed, large firms have been thoroughly developed these activities in the last few decades. Similarly, large industries and incumbent firms have conducted accumulation processes, in which have concentrated on key activities (production, distribution and R\&D) that have enabled them to increase their productivity. These processes of industrial development are related to the period of scale and scope (Chandler, Hikino 1996). The relationship between entrepreneurship and large firms can be explained from creative destruction concept and creative accumulation as an economic system dynamics (Backhaus 2003). Creative destruction highlights the importance of the role of the entrepreneur because it is considered as the prime cause of the economic development where one of this characteristic is the proliferation of small firms (Carree, Thurik 2010). On the other hand, creative accumulation emphasises its attention on the innovative activities, which are developed by large industries and incumbent firms forming a concentrated market structure (Carree, Thurik 2010). The development of some of these types of industries is given by the stage of development of the country in which they are located (Verheul et al. 2002). In fact, high levels of research and innovation are more intensive in big industries while the development of innovative advantage comes from gaps of market that small and new business has detected enabling the development of a small-scale production within the service economy. Indeed, countries with high levels of research and innovation are more likely to develop and foster small and new business that provide an innovative advantage. Thus, depending on the state of development of a country, this can create specific conditions for entrepreneurship.

Hence, the market and the industrial structure determine the creation of opportunities to entrepreneurship and technological development, globalization and economic development influence it (Verheul et al. 2002). The demand for entrepreneurship is configured by these sets of factors where environmental factors create conditions for the entrepreneurial activity. Thus, the selection of business opportunity and makes a decision for potential entrepreneurs have a degree of uncertainty because it considers multiple variables related to risk and reward. Indeed, the entrepreneur decision making take into account personal preferences, environmental factors, individual characteristics, which depends on weighing risk-rewards between self-employment and salary employment (Wennekers, Thurik 1999; Verheul et al. 2002). Furthermore, there are factors as the changing markets conditions and a possible increase of the opportunity costs, which cause more uncertainty in the individual, hindering the process of entrepreneurial decision-making. Hence, the treatment of personal characteristics and intuition of the entrepreneur can contribute to fostering new 
entrepreneurial initiatives (Cuervo 2005; Merigó, Peris-Ortiz 2014). Currently, in soft computing science are being developing techniques that allow processing personal preferences and the attitudinal character. Thus, with the use of these techniques, the decision maker can take a decision to invest and to create a new firm in the most appropriate market within a complex environment (Merigó, Peris-Ortiz 2014; Merigó et al. 2014).

\subsection{Decision making with the ordered weighted averaging (OWA) operator}

The ordered weighted averaging (OWA) operator is an instrument that allows aggregating information obtaining a single representative value of the information. The OWA operator meets the parameters of considered optimism and pessimism in an aggregated value. The OWA operator unifies the criteria of Optimist, Pessimist, Hurwicz and de Laplace in a single formulation (Yager 1988). Likewise, the OWA operator can aggregate information differently depending on its degree of pessimism or optimism (Gil-Lafuente, Merigó 2009), which are defined by limits the minimum and maximum. Based on OWA operator, new aggregation operators have developed new aggregation operators providing a parameterized family (Emrouznejad, Marra 2014; Merigó, Gil-Lafuente 2012a). In this sense, Yager (1993) proposed OWA operator families; Yager and Kelman (1999) suggested analytical hierarchy process, Yager and Kacprzyk (1997) and Yager et al. (2011) developed applications of OWA operator, Herrera (1995), Herrera and Martinez (2000) and Xu (2004) developed works focused on linguistic OWA operator. Furthermore, it has been developed aggregation operators in combination with OWA operator and other instruments. Merigó (2009) Gil-Lafuente and Merigó (2007) Merigó and Gil-Lafuente (2006, 2008a, 2008b, 2008c, 2013) suggested distance and index selection for OWA operators, Wei (2009) developed an induced linguistic hybrid geometric aggregation of OWA operators, Zhao et al. (2010) proposed OWA operators for intuitionistic fuzzy sets, Zhou and Chen (2010) worked in logarithm aggregation in OWA operators, Peng and Ye (2014) introduced the induced uncertain pure linguistic hybrid harmonic averaging operator, Xu et al. (2014) proposed intuitionistic fuzzy Einstein Choquet integral operators, Zhou et al. (2014) suggested intuitionistic fuzzy weighted cosine similarity measure, He et al. (2014) introduced an intuitionistic fuzzy geometric, Wei et al. (2014) worked on multiple attribute decision making, Peng et al. (2014) suggested non-homogenous preferences information, He et al. (2015a) proposed intuitionistic fuzzy information, He et al. (2015b) introduced fuzzy interaction Bonferroni, He et al. (2015c) suggested hesitant fuzzy power Bonferroni. All these operators offer multiple techniques that can be used to solve decision-making problems. Furthermore, some of these applications are used in the process of decision-making over uncertainty in several fields.

In business and economic field, some techniques are used to dealing with uncertainty and opinion of the decision-maker, specially, when there are not shortage of information and high level of subjectivity. Firstly, we have Hamming distance (HD) (Hamming 1950), which allow aggregating information and being used when a strictly established figure is considered as the ideal, i.e., it is not a threshold with valid results (Merigó 2010). Secondly, we have adequacy coefficient (AC) (Kaufmann, Gil-Aluja 1986, 1987), which is an 
extension of HD and allows analysing the information when the results are higher than the ideal by using a t-norm. Thirdly, we have the index of maximum and minimum level (IMAM) (Gil-Lafuente 2001, 2002), which combines the characteristics of HD and AC in the same formulation (Merigó, Gil-Lafuente 2010; Merigó et al. 2011, 2013; Merigó, GilLafuente 2012a, 2012b) and allows taking into account the situation in which it is as good to achieve the ideal level as to overcome it. Thus, it is noteworthy that these techniques let the decision-maker can take a decision according to its interests. Besides, decision-maker can also focus on the results obtained in different situations, based on its optimism degree (Merigó 2010). Recently, using these techniques with OWA, it has been developed new aggregation operators, which are called selection indices (SI): Gil-Lafuente and Merigó (2007), Merigó (2009) and Merigó and Gil-Lafuente (2010) have proposed the ordered weighted averaging distance (OWAD) and Merigó (2010), Merigó and Gil-Lafuente (2012a; 2012b) have suggested the ordered weighted averaging adequacy coefficient (OWAAC) operator and ordered weighted averaging index of maximum and minimum level (OWAIMAM) operator. These new extensions are used in business and economics decision-making problems as entrepreneurship, human resources, investment, marketing, strategy, production, policy-making, regional development and public economics. Furthermore, it is noteworthy that these new operators reflecting the attitudinal character of the decision-maker at the time of decision-making.

\section{Case study}

Case study is focused on entrepreneurial conditions, stage of economy development and problematic condition for doing business in Colombia. Mathematical experiment is oriented to start new business in the sports sector. Since the 1990s, Colombia has adopted policies toward enhancing competitiveness in order to improve the macroeconomic conditions (CEC 2012). However, in the last competiveness report, Colombia has evidenced the existence of weak institutions and a considerable corruption, transport infrastructure insufficiency, failures of the education system and lack of diversification in the economic base as well (WEF 2014). Currently, Colombia is a stage of efficiency-drive economy, which is characterized by its efficiency production process and increasing product quality (WEF 2014). This stage of the economy develops special environment characteristics for doing business and starting new businesses. Structural conditions that affect the business dynamic, business opportunities, personal business preferences and decision-making processes of individuals are composed by these characteristics, which can be defined by key entrepreneurial framework conditions (EFC's). Colombia's EFC's, compared to other economies, show negative differences in financing, legal, trade and physical infrastructure, $\mathrm{R} \& \mathrm{D}$ transfer, dynamics and opening of domestic market and social norms (GEM Colombia 2014). However, Colombia has shown a considerable enhancement on macroeconomic environment, specially in trade, investment and fiscal freedom, which has aided to become a "mostly free" economy and increasing investor confidence (Miller et al. 2014).

Sports have become a dynamic and attractive economic sector (Heinemann 1994), where both public and private sector take part in its development. Nowadays, sport has 
generated a huge global interest, which has become an economically attractive sector, creating a great deal of opportunities for the development of new sports business (Ratten, V., Ratten, H. 2011). According to Heinemann (1994) these opportunities arise when demand is stimulated by new welfare needs. In order to supply these new needs, suppliers offer new services, goods, locations and forms of consumption in line with the aspiration of the customers. Likewise, these are complemented with activities related to leisure and recreation. Furthermore, it is noteworthy that professional and spectacle sports support the potential of sports business because they receive financial resources both for public and private sectors. Besides, mass media promotes its local and international consumption, improving the revenues. Finally, sports business initiatives are able to affect different areas of the economy through its social impact (Ratten, V., Ratten, H. 2011). Thus, the development of the sports sector in Colombia can have a chance of growing, since the current environmental conditions, the existing structure market and the sports movement can stimulate the creation of new businesses.

\section{Methodology}

In this paper, we have proposed a new algorithm for decision-making process under uncertainty. Likewise, we have also developed an application that allows the comparison and the selection between new several business alternatives. To develop case study, we have taken into account some industries of the sports sector and some critical environmental factors that influence the competitiveness and entrepreneurship in Colombia to start a new business. In order to carry out mathematical application, we use the Colombia's resulting data contents within global competitiveness report (GCR) and global entrepreneurship monitor (GEM) in the period 2013-2014.

\subsection{Global competitiveness index (GCI)}

The global competitiveness report (GCR) provides the global competitiveness index (GCI), which allows assesses the national competitiveness worldwide from drivers of their productivity and prosperity (WEF 2014). GCI is supported by 12 different pillars of competitiveness, which determine 3 stages of development and 2 stage of transition. The first stage is called factor-driven and is related to pillars from 1 to 4 . It is noteworthy that countries within this stage develop economies based on natural resources endowments and primarily unskilled labour. The second stage is called efficiency-driven and is related to pillars from 5 to 10. Countries within this stage develop more efficient production processes and increase product quality. Thus, for a country to move from stage 1 to stage 2, it must improve industrialization, raise wages and become more capital intensive in order to become more competitive. The third stage is called innovation-driven and is related to pillars 11 and 12. Countries within this stage are characterized by the use of the most sophisticated production processes and innovation in order to produce new and different goods and services. Thus, for a country to move from stage 2 to stage 3, their companies must be at the global technological frontier (WEF 2014). It is highlighted that pillars tend to reinforce 
each other, and a weakness in one area often has a negative impact in the others (WEF 2014). In addition, the GCR's highlights and assesses the most problematic factors for doing business (Table 1). These resulting data are significant for the study. This table summarizes those factors seen by business executives as the most problematic ones when doing business in their economy. From a list of 16 factors, respondents were asked to select the five most problematic and rank them from 1 (most problematic) to 5 . The results were then tabulated and weighted according to the ranking assigned by respondents.

Table 1. The most problematic factors for doing business

\begin{tabular}{clll}
\hline Vector $w_{P F}$ & \multicolumn{1}{c}{ Problematic factors } & Vector $w_{P F}$ & \multicolumn{1}{c}{ Problematic factors } \\
\hline$w_{P F} 1$ & access to financing & $w_{P F} 9$ & inflation \\
\hline $\mathrm{w}_{P F} 2$ & crime and theft & $w_{P F} 10$ & insufficient capacity to innovate \\
\hline$w_{P F} 3$ & corruption & $w_{P F} 11$ & policy instability \\
\hline$w_{P F} 4$ & foreign currency regulations & $w_{P F} 12$ & poor public health \\
\hline$w_{P F} 5$ & government instability/coups & $w_{P F} 13$ & poor work ethic/labor force \\
\hline$w_{P F} 6$ & inadequately educated workforce & $w_{P F} 14$ & restrictive labor regulations \\
\hline$w_{P F} 7$ & inadequate supply of infrastructure & $w_{P F} 15$ & tax rates \\
\hline$w_{P F} 8$ & inefficient government bureaucracy & $w_{P F} 16$ & tax regulations \\
\hline
\end{tabular}

Source: Global Competitiveness Report, 2013-2014 (WEF 2014).

\subsection{Global entrepreneurship monitor (GEM)}

Global entrepreneurship monitor (GEM) provides significant information of the level of entrepreneurship within a country. One of its key goals is helping establishing the way entrepreneurship relates to economic growth and, in a longer-term perspective, economic development. The report also shows the entrepreneurial behaviour and attitudes of the individuals (GEM 2014). These factors mentioned above, we allow understudying of the entrepreneurship environment, which are represented on entrepreneurial framework conditions (EFC's) (see Table 2) (GEM 2008).

Both reports give information about environmental conditions within economic space. On the one hand, we have considered factors that have considerably influenced at doing business. On the other hand, we have considered factors that define the necessary conditions to entrepreneur (EFC's). In this sense, we assume that a group entrepreneur potentials desire to start a new business within an industry of sports sector and they want to choose the best option among a group of existing opportunities. Thus, in order to aggregate and order economic information and entrepreneur expectations, we use the OWA operator. Since our main aim is to make a selection, we use selection indices, OWAD operator, OWAAC operator, OWAIMAM operator. These operators allow achieving an accurate representation of the decision-making problem, because they take into account the situations where it is as good to get a particular ideal level as to surpass it. Right after now, aggregator operators and its extensions will be defined. 
Table 2. Key entrepreneurial framework conditions (EFC’s)

\begin{tabular}{llll}
\hline \multicolumn{1}{c}{ EFC's } & \multicolumn{1}{c}{ EFC's } \\
\hline $\mathrm{C}_{1}$ & $\begin{array}{l}\text { Finances: financial resources-equity } \\
\text { and debt-for small and medium } \\
\text { enterprises (SMEs) }\end{array}$ & $\mathrm{C}_{7}$ & $\begin{array}{l}\text { R\&D transfer: national research and } \\
\text { development will lead to new commercial } \\
\text { opportunities }\end{array}$ \\
\hline $\mathrm{C}_{2}$ & $\begin{array}{l}\text { National policy-general policy: } \\
\text { public policies give support to } \\
\text { entrepreneurship }\end{array}$ & $\mathrm{C}_{8}$ & $\begin{array}{l}\text { Commercial infrastructure: property rights, } \\
\text { commercial, accounting and other legal and } \\
\text { assessment services and institutions }\end{array}$ \\
\hline $\mathrm{C}_{3}$ & $\begin{array}{l}\text { National policy-regulation: taxes and } \\
\text { regulations }\end{array}$ & $\mathrm{C}_{9}$ & $\begin{array}{l}\text { Internal market-dynamics: the level of change } \\
\text { in markets from year to yea }\end{array}$ \\
\hline $\mathrm{C}_{4}$ & $\begin{array}{l}\text { Government programs: the presence } \\
\text { and quality of programs directly } \\
\text { assisting SMEs }\end{array}$ & $\mathrm{C}_{10}$ & $\begin{array}{l}\text { Internal market-openness: the extent to which } \\
\text { new firms are free to enter existing markets }\end{array}$ \\
\hline $\mathrm{C}_{5} \begin{array}{l}\text { Entrepreneurship education-primary } \\
\text { and second }\end{array}$ & $\mathrm{C}_{11}$ & $\begin{array}{l}\text { Physical infrastructure: access to physical } \\
\text { resources-communication, utilities, } \\
\text { transportation, land or space }\end{array}$ \\
\hline $\mathrm{C}_{6}$ & $\begin{array}{l}\text { Entrepreneurship education-post- } \\
\text { school }\end{array}$ & $\mathrm{C}_{12}$ & $\begin{array}{l}\text { Culture and social norms: norms encourage or } \\
\text { allow actions leading to new business methods }\end{array}$ \\
\hline
\end{tabular}

Source: Based on Global Entrepreneurship Monitor 2013 Global Report (Amorós, Bosma 2014: 45).

\subsection{HD, AC, IMAM, OWAD, OWAAC AND OWAIMAM definitions}

In this section, we briefly review some basic concepts about the Hamming distance, the adequacy coefficient (AC), the index of maximum and minimum level (IMAM) and their extensions with the OWA operator, which are used throughout the paper.

\subsubsection{The Hamming distance}

The Hamming distance (Hamming 1950) is a useful technique to calculate the differences between two elements, two sets, etc. In fuzzy set theory, it can be useful, for example, for the calculation of distances between fuzzy sets, interval-valued fuzzy sets, intuitionistic fuzzy sets and interval-valued intuitionistic fuzzy sets. For two sets A and B, the weighted Hamming distance can be defined as the following:

Definition 1. A weighted Hamming distance of dimension $\mathrm{n}$ is a mapping $d_{W H}: R^{n} x R^{n} \rightarrow R$ that has an associated weighting vector $W$ of dimension $n$ with the sum of the weights being 1 and $w_{j} \in[0,1]$ such that:

$$
d_{W H}\left(\left\langle x_{1}, y_{1}\right\rangle, \ldots,\left\langle x_{n}, y_{n}\right\rangle\right)=\sum_{j=1}^{n} w_{j}\left|x_{i}-y_{i}\right|,
$$

where $x_{1}$ and $y_{1}$ are the ith arguments of the sets $X$ and $Y$.

\subsubsection{The adequacy coefficient}

The adequacy coefficient (Kaufmann, Gil-Aluja 1986, 1987) is an index that is used for calculating the differences between two elements or two sets. It is very similar to the Hamming distance, but the difference is that it neutralizes the result when the comparison shows that 
the real element is higher than the ideal one. For two sets A and B, the weighted adequacy coefficient can be defined as follows:

Definition 2. A weighted adequacy coefficient of dimension $n$ is a mapping $K:[0,1]^{n} x[0,1]^{n}$ $\rightarrow[0,1]$ that has an associated weighting vector $W$ of dimension $\mathrm{n}$ with the sum of the weights 1 and $w_{j} \in[0,1]$ such that:

$$
K\left(\left\langle x_{1}, y_{1}\right\rangle, \ldots,\left\langle x_{n}, y_{n}\right\rangle\right)=\sum_{j=1}^{n} w_{j}\left[1 \wedge\left(1-x_{1}+y_{i}\right)\right],
$$

where $x_{1}$ and $y_{1}$ are the $i$ th arguments of the sets $X$ and $Y$.

\subsubsection{The index of maximum and minimum level}

The index of maximum and minimum level is an index that unifies the Hamming distance and the adequacy coefficient in the same formulation (Gil-Lafuente 2001, 2002). For two sets $A$ and $B$, the weighted index of maximum and minimum level can be defined as follows:

Definition 3. An AWIMAM of dimension $\mathrm{n}$ is a mapping $K:[0,1]^{n} x[0,1]^{n} \rightarrow[0,1]$ that has an associated weighting vector $W$ of dimension $n$ with the sum of the weights 1 and $w_{j} \in$ $[0,1]$ such that:

$$
\eta\left(\left\langle x_{1}, y_{1}\right\rangle, \ldots,\left\langle x_{n}, y_{n}\right\rangle\right)=\sum_{u} Z_{i}(u) *\left|x_{i}(u)-y_{i}(u)\right|+\sum_{v} Z_{i}(v) *\left[0 \vee x_{i}(v)-y_{i}(v)\right],
$$

where $x_{1}$ and $y_{1}$ are the ith arguments of the sets $X$ and $Y$.

\subsubsection{The OWA operator}

The OWA operator (Yager 1988) provides a parameterized class of mean type of aggregation operators. It can be defined as follows:

Definition 4. An OWA operator of dimension $n$ is a mapping OWA: $R^{n} \rightarrow R$ that has an associated weighting vector $W$ of dimension $n$ with $w_{j} \in[0,1]$ and $\sum_{j=1}^{n} w_{j}=1$, such that:

where $b_{j}$ is the $j t h$ largest of the $a_{i}$.

$$
\operatorname{OWA}\left(a_{1}, a_{2}, \ldots, a_{n}\right)=\sum_{j=1}^{n} w_{j} b_{j}
$$

The OWAAC operator (Merigó, Gil-Lafuente 2008b, 2010; Gil-Lafuente, Merigó 2009) is an aggregation operator that uses the adequacy coefficient and the OWA operator in the same formulation. It can be defined as follows for two sets $\mathrm{X}$ and $\mathrm{Y}$.

Definition 5. An OWAAC operator of dimension $\mathrm{n}$ is a mapping OWAAC: $[0,1]^{n} x[0,1]^{n} \rightarrow$ $[0,1]$ that has an associated weighting vector $W$, with $w_{j} \in[0,1]$ and $\sum_{j=1}^{n} w_{j}=1$, such that:

$$
\operatorname{OWAAC}\left(\left\langle x_{1}, y_{1}\right\rangle, \ldots,\left\langle x_{n}, y_{n}\right\rangle\right)=\sum_{j=1}^{n} w_{j} K_{j},
$$

where $K_{j}$ represents the $j$ th largest of $\left[1 \wedge\left(1-x_{1}+y_{i}\right)\right], x_{i}, y_{i} \in[0,1]$. 
The OWAD operator (Gil-Lafuente, Merigó 2007; Merigó 2009; Merigó, Gil-Lafuente $2010)$ is an aggregation operator that uses OWA operators and distance measures in the same formulation. It can be defined for two sets $X$ and $Y$.

Definition 6. An OWAD operator of dimension $\mathrm{n}$ is a mapping OWAD: $R^{n} x R^{n} \rightarrow R$ that has an associated weighting vector $W, \sum_{j=1}^{n} w_{j}=1$ and $w_{j} \in[0,1]$ such that:

$$
\operatorname{OWAD}\left(\left\langle x_{1}, y_{1}\right\rangle, \ldots,\left\langle x_{n}, y_{n}\right\rangle\right)=\sum_{j=1}^{n} w_{j} D_{j}
$$

where $D_{j}$ represents the $j$ th largest of the $\left|x_{i}-y_{i}\right|$.

The OWAIMAM operator (Merigó 2009; Merigó, Gil-Lafuente 2011, 2012b; Merigó et al. 2011) is an aggregation operator that uses the Hamming distance, the adequacy coefficient and the OWA operator in the same formulation. It can be defined as it follows:

Definition 7. An OWAIMAM operator of dimension $\mathrm{n}$, is a mapping OWAIMAM:[0,1] ${ }^{n} x[0,1]^{n} \rightarrow[0,1]$ that has an associated weighting vector $W$, with $w_{j} \in[0,1]$ and the sum of the weights is equal to 1 , such that:

$$
\operatorname{OWAIMAM}\left(\left\langle x_{1}, y_{1}\right\rangle,\left\langle x_{2}, y_{2}\right\rangle, \ldots,\left\langle x_{n}, y_{n}\right\rangle\right)=\sum_{j=1}^{n} w_{j} K_{j},
$$

where $K_{j}$ represents the $j$ th largest of all the $\left|x_{i}-y_{i}\right|$ and the $\left[0 \vee\left(x_{i}, y_{i}\right)\right]$.

\section{A new method to deal with the weight of the OWA operator}

Following (Gil-Aluja 1999) information can be aggregated according to the significance of its characteristics. Thus, this proposition allows aggregating information according to a certain level all characteristics because it takes into account the importance of the relationship of each characteristic, which is considered to make a decision. In order to deal with a decision-making problem, the following proposition is realized.

Proposition 1. An OWAAC operator with fuzzy-significance can have a weighting vector $W$, with $w_{j} \in[0,1]$ and $\sum_{j=1}^{n} \frac{w_{j}}{\max \left(w_{j}\right)}$, such that:

$$
F S-O W A A C\left(\left\langle x_{1}, y_{1}\right\rangle, \ldots,\left\langle x_{n}, y_{n}\right\rangle\right)=\sum_{j=1}^{n} \frac{w_{j}}{\max \left(w_{j}\right)} K_{j},
$$

where $K_{j}$ represents the $j$ th largest of $\left[1 \wedge\left(1-x_{1}+y_{i}\right)\right], x_{i}, y_{i} \in[0,1]$.

Proposition 2. An OWAD operator with fuzzy-significance can have a weighting vector $W, \sum_{j=1}^{n} \frac{w_{j}}{\max \left(w_{j}\right)}$, and $w_{j} \in[0,1]$ such that:

$$
F S-O W A D\left(\left\langle x_{1}, y_{1}\right\rangle, \ldots,\left\langle x_{n}, y_{n}\right\rangle\right)=\sum_{j=1}^{n} \frac{w_{j}}{\max \left(w_{j}\right)} D_{j},
$$

where $D_{j}$ represents the $j$ th largest of the $\left|x_{i}-y_{i}\right|$. 
Proposition 3. An OWAIMAM with fuzzy-significance can have a weighting vector $W$, with $w_{j} \in[0,1]$ and $\sum_{j=1}^{n} \frac{w_{j}}{\max \left(w_{j}\right)}$, such that:

$$
\text { FS-OWAIMAM }\left(\left\langle x_{1}, y_{1}\right\rangle, \ldots,\left\langle x_{n}, y_{n}\right\rangle\right)=\sum_{j=1}^{n} \frac{w_{j}}{\max \left(w_{j}\right)} K_{j},
$$

where $K_{j}$ represents the $j$ th largest of all the $\left|x_{i}-y_{i}\right|$ and the $\left[0 \vee\left(x_{i}, y_{i}\right)\right]$.

Note that it is easy to obtain a result higher than the maximum; hence, the boundary and idempotency condition is not accomplished in the operator. This occurs because the sum of the weights can be higher than one. Thus, we carry out a normalization process (Merigó, Gil-Lafuente 2009) in order to accomplish the boundary condition. A practical method for doing so is by dividing the weights by the sum of all of them. Therefore, this operator is very useful as a method for decision-making but it does not represent the information from a classical point of view.

These OWA operators are commutative, monotonic, non-negative and reflexive. They are commutative from the OWA perspective because $f\left(\left\langle x_{1}, y_{1}\right\rangle, \ldots,\left\langle x_{n}, y_{n}\right\rangle\right)=f\left(\left\langle c_{1}, d_{1}\right\rangle\right.$, $\left.\ldots,\left\langle c_{n}, d_{n}\right\rangle\right)$ where $\left(\left\langle x_{1}, y_{1}\right\rangle, \ldots,\left\langle x_{n}, y_{n}\right\rangle\right)$ is any permutation of the arguments $\left(\left\langle c_{1}, d_{1}\right\rangle, \ldots\right.$, $\left.\left\langle c_{n}, d_{n}\right\rangle\right)$. They are also commutative from the distance measure perspective because $f\left(\left\langle x_{1}\right.\right.$, $\left.\left.y_{1}\right\rangle, \ldots,\left\langle x_{n}, y_{n}\right\rangle\right)=f\left(\left\langle y_{1}, x_{1}\right\rangle, \ldots,\left\langle y_{n}, x_{n}\right\rangle\right)$. They are monotonic because if $\left|x_{i}-y_{i}\right| \geq\left|c_{i}-d_{i}\right|$, for all $i$, then $f\left(\left\langle x_{1}, y_{1}\right\rangle, \ldots,\left\langle x_{n}, y_{n}\right\rangle\right) \geq f\left(\left\langle c_{1}, d_{1}\right\rangle, \ldots,\left\langle c_{n}, d_{n}\right\rangle\right)$. Non-negativity is also accomplished always, that is, $f\left(\left\langle x_{1}, y_{1}\right\rangle, \ldots,\left\langle x_{n}, y_{n}\right\rangle\right) \geq 0$. Finally, they are also reflexive because $f$ $\left(\left\langle x_{1}, x_{1}\right\rangle, \ldots,\left\langle x_{n}, x_{n}\right\rangle\right)=0$.

Another important issue is to consider the formulation for the characterization of the weighting vector under this framework: the degree orness/andness (degree of optimism or pessimism) (Yager 1988) is defined in the following way with this new approach:

$$
\alpha(w)=\sum \frac{n-j}{n-1} * \frac{w_{j}}{\max \left(w_{j}\right)},
$$

where $\min \rightarrow 0$, even though the maximum can be higher than 1 . By the introduction of significance degree in more than one variable is where the result is not contained in $[0,1]$.

The entropy of dispersion (Shannon 1948; Yager 1988) can be defined as follows:

$$
H(w)=-\sum_{j=1}^{n}\left(\frac{w_{j}}{\max \left(w_{j}\right)}\right) \ln \left(\frac{w_{j}}{\max \left(w_{j}\right)}\right) .
$$

Finally, let us briefly study some key particular cases of these operators. If one of the sets is empty, we get the FS-OWA operator in the FS-OWAD. In the FS-OWAAC, if X is empty all the individual comparisons are 1 , so the result is 1 or higher. The FS-OWAIMAM is a combination of the previous ones.

If $w_{1}=1$ and $w_{j}=0$ for all $j \neq 1$, we get the maximum distance, FS-OWAD $=\operatorname{Max}\left\{D_{j}\right\}$ and if $w_{n}=1$ and $w_{j}=0$ for all $j \neq n$, the minimum distance, FS-OWAD $=\operatorname{Min}\left\{D_{j}\right\}$. Note that similar results are also found with the FS-OWAAC and the FS-OWAIMAM operator. If $w_{j}=1 / n$, for all $j$, the result is the total operator, which is also the sum of all the individual distances (Merigó et al. 2014). This occurs because in this situation all the weights are $(1 / n) /(1 / n)=1$ so the sum is $n$. The result obtained is the absolute distance. 
The step-FS-OWA aggregation (Yager 1993) provides the same results than the classical OWA approach. The median-FS-OWA aggregation (Merigó, Gil-Lafuente 2009) gives the same results only when it is odd. If it is even, the results of the FS-OWAD are twice as high as they should in the classical framework. The Olympic-FS-OWAD (Merigó, Gil-Lafuente 2009; Yager 1993) is used when $w_{1}=w_{n}=0$, and for all others $w_{j^{*}}=1 /(n-2)$. In this case, the result is $n-2$ which is close to the total and has close connections with the arithmetic distance.

\section{Application}

Now, we present an application of the new operator proposed. The main advantage on using OWA operators is that they can overestimate information according to attitudinal character of the decision-maker. The application is centred on a sample selection of business opportunities between six industries in the sports sector.

\subsection{Mathematical approach for decision making}

The new operator allows comparing between each alternative in order to select option according environmental information and attitude of entrepreneur. The procedure is designed in four steps, which are described as follows:

Step 1 . We assumed that the entrepreneurs want to select an industry to start a business within the sports sector, and there are six possible options $\mathrm{NB}_{1}, \mathrm{NB}_{2}, \mathrm{NB}_{3}, \mathrm{NB}_{4}, \mathrm{NB}_{5}$ and $\mathrm{NB}_{6}$, which have different characteristics (see Table 3 ). In this case, each characteristic of the sector is considered a property.

Table 3. Sports industries business opportunity

\begin{tabular}{ll}
\hline $\mathrm{NB}_{1}$ & Textile and manufacturing industry \\
\hline $\mathrm{NB}_{2}$ & Sports services \\
\hline $\mathrm{NB}_{3}$ & Sports and leisure events \\
\hline $\mathrm{NB}_{4}$ & Sports management consultancy services \\
\hline $\mathrm{NB}_{5}$ & Media \\
\hline $\mathrm{NB}_{6}$ & Marketing, selling and distributions \\
\hline
\end{tabular}

Source: Own elaboration.

Step 2. It has fixed real level and the ideal conditions for each significant characteristic. The real level is current conditions available under the environment to start a business in Colombia (see Table 4). The ideal conditions define the necessary conditions for entrepreneur an economic activity (see Table 5). 
Table 4. Real level: Colombia’s EFC's rates

\begin{tabular}{clc}
\hline variable $\mathrm{X}$ & \multicolumn{1}{c}{ EFC's } & Rates \\
\hline $\mathrm{C}_{1}$ & finances & 2.3 \\
\hline $\mathrm{C}_{2}$ & national policy-general policy & 2.8 \\
\hline $\mathrm{C}_{3}$ & national policy-regulation & 2.6 \\
\hline $\mathrm{C}_{4}$ & government programs & 3 \\
\hline $\mathrm{C}_{5}$ & education-primary and second & 2.3 \\
\hline $\mathrm{C}_{6}$ & education-post-school & 3.2 \\
\hline $\mathrm{C}_{7}$ & R\&D transfer & 2.4 \\
\hline $\mathrm{C}_{8}$ & commercial infrastructure & 2.8 \\
\hline $\mathrm{C}_{9}$ & internal market-dynamics & 2.9 \\
\hline $\mathrm{C}_{10}$ & internal market-openness & 2.8 \\
\hline $\mathrm{C}_{11}$ & physical infrastructure & 3.3 \\
\hline $\mathrm{C}_{12}$ & culture and social norms & 3.1 \\
\hline
\end{tabular}

Source: Own elaboration based on Global Entrepreneurship Monitor 2013-2014 (GEM 2014).

Table 5. Ideal conditions for entrepreneur

\begin{tabular}{ccccccccccccc}
\hline $\mathrm{X}$ & $\mathrm{C}_{1}$ & $\mathrm{C}_{2}$ & $\mathrm{C}_{3}$ & $\mathrm{C}_{4}$ & $\mathrm{C}_{5}$ & $\mathrm{C}_{6}$ & $\mathrm{C}_{7}$ & $\mathrm{C}_{8}$ & $\mathrm{C}_{9}$ & $\mathrm{C}_{10}$ & $\mathrm{C}_{11}$ & $\mathrm{C}_{12}$ \\
\hline Colombia & 0.46 & 0.56 & 0.52 & 0.6 & 0.46 & 0.64 & 0.48 & 0.56 & 0.58 & 0.56 & 0.66 & 0.62 \\
\hline
\end{tabular}

Source: Own elaboration based on EFC's rates Table 1.

Step 3. It has fixed the necessary conditions of each characteristic to start a different business opportunity in a sports industry. Here, each characteristic can consider objective or subjective information, which is provided by expert specifications and its suggestions. They recommend the most necessary conditions to start a business opportunity highlighting its degree of importance. In this case, hypothetical degrees of level in each characteristic for each of the options have been proposed (see Table 6).

Table 6. Necessary conditions to start a new business in a sports industry

\begin{tabular}{ccccccccccccc}
\hline $\mathrm{Y}$ & $\mathrm{C}_{1}$ & $\mathrm{C}_{2}$ & $\mathrm{C}_{3}$ & $\mathrm{C}_{4}$ & $\mathrm{C}_{5}$ & $\mathrm{C}_{6}$ & $\mathrm{C}_{7}$ & $\mathrm{C}_{8}$ & $\mathrm{C}_{9}$ & $\mathrm{C}_{10}$ & $\mathrm{C}_{11}$ & $\mathrm{C}_{12}$ \\
\hline $\mathrm{NB}_{1}$ & 0.1 & 0.6 & 0.4 & 0.8 & 0.4 & 0.7 & 0.7 & 0.8 & 0.7 & 0.7 & 0.9 & 0.9 \\
\hline $\mathrm{NB}_{2}$ & 0.4 & 0.6 & 0.4 & 0.2 & 0.7 & 0.6 & 0.3 & 0.6 & 0.6 & 0.6 & 0.7 & 0.6 \\
\hline $\mathrm{NB}_{3}$ & 0.6 & 0.6 & 0.5 & 0.5 & 0.7 & 0.6 & 0.3 & 0.6 & 0.1 & 0.3 & 0.9 & 0.9 \\
\hline $\mathrm{NB}_{4}$ & 0.1 & 0.6 & 0.5 & 0.3 & 0.7 & 0.9 & 0.2 & 0.2 & 0.5 & 0.7 & 0.5 & 0.3 \\
\hline $\mathrm{NB}_{5}$ & 0.1 & 0.6 & 0.7 & 0.2 & 0.3 & 0.6 & 0.3 & 0.4 & 0.1 & 0.1 & 0.7 & 0.6 \\
\hline $\mathrm{NB}_{6}$ & 0.1 & 0.6 & 0.2 & 0.2 & 0.6 & 0.6 & 0.5 & 0.8 & 0.6 & 0.7 & 0.7 & 0.9 \\
\hline
\end{tabular}

Source: Own elaboration.

Step 4. We have used the FS-OWA to make a comparison between the EFC's in Colombia and the different options. It will consider the FS-OWAAC, the FS-OWAIMAM and the FS-OWAD operator. In this application, we assume that the experts decide that the most problematic factors for doing business in Colombia are considered as the weighting 
vectors $W_{P F}$ (see Table 7). Each of the factors is selected from the (WEF 2014). The main idea is to aggregate and compare how environmental conditions in combination with attitudinal character of the decision-maker can influence and guide the decision to start a new business.

Table 7. Colombia’s PF for doing business rates

\begin{tabular}{cccccccc}
\hline vector $w_{P F}$ & rates $\%$ & $\mathrm{~N}$ & $\mathrm{IN}$ & vector $w_{P F}$ & rates $\%$ & $\mathrm{~N}$ & $\mathrm{IN}$ \\
\hline$w_{P F} 1$ & 20.2 & 1 & 0 & $w_{P F} 9$ & 3.3 & 0.163 & 0.837 \\
\hline $\mathrm{w}_{P F} 2$ & 14.6 & 0.723 & 0.277 & $w_{P F} 10$ & 2.8 & 0.139 & 0.861 \\
\hline$w_{P F} 3$ & 12.2 & 0.604 & 0.396 & $w_{P F} 11$ & 2.4 & 0.119 & 0.881 \\
\hline$w_{P F} 4$ & 8.1 & 0.401 & 0.599 & $w_{P F} 12$ & 2.3 & 0.114 & 0.886 \\
\hline$w_{P F} 5$ & 8.1 & 0.401 & 0.599 & $w_{P F} 13$ & 1.8 & 0.089 & 0.911 \\
\hline$w_{P F} 6$ & 7.7 & 0.381 & 0.619 & $w_{P F} 14$ & 1.7 & 0.084 & 0.916 \\
\hline$w_{P F} 7$ & 7.4 & 0.366 & 0.634 & $w_{P F} 15$ & 0.9 & 0.045 & 0.955 \\
\hline$w_{P F} 8$ & 6.3 & 0.312 & 0.688 & $w_{P F} 16$ & 0.2 & 0.01 & 0.99 \\
\hline
\end{tabular}

Source: Own elaboration based on Global Competitiveness Report, 2013-2014 (WEF 2014). Note that resulting data has been Normalized (N) to establish the weight of each factor and Inverse Normalized (IN) for showing positive factor effects.

\subsection{Results}

We were proposed and implemented the new weighting vector $W_{P F}$, which are called FSOWAAC operator, the FS-OWAIMAM operator, and the FS-OWAD operator. We elaborated two different applications of the FS-OWAIMAM operator, since this operator uses the Hamming distance and the adequacy coefficient simultaneously. Thus, it is shown the versatility of this operator to aggregate preferences of the decision-makers. Furthermore, FS-OWAAC provides more widespread results, while FS-OWAD and FS-OWAIMAM provide more specific results. Finally, we have ordered and charted the results obtained from the comparison between each single considered industry. It is noteworthy that these operators allowed aggregating objective - resulting data - and subjective - necessary condition - information to obtain a characteristic value for each of the alternative $\mathrm{NB}_{\mathrm{n}}$ suggested within an uncertain environment. We have calculated the vector $W_{P F}$ with 16 cases (see Tables 8 to 11) and its influence at doing business according to new business opportunity. After that, each alternative NBn was ordered according to average vectors (Ave) in each table. Results obtained from the FS-OWAAC are sorted in descending order because in this case the highest average is the most favourable alternative. Results obtained from FS-OWA operator are sorted in ascending order because the lowest average is the most favourable alternative. It is noteworthy that each alternative reflects a different degree of optimism or pessimism concerning the weighting vector. There is an interesting issue regarding the degree of optimism for the vector $W_{P F} 1$, since it is the lowest vector and has a negative influence in an individual decision-making. Likewise, vectors allow observing differences between each of the alternatives, which appear to be small. However, it is important to highlight that although the differences are small, into a macroeconomic context, they have a different connotation, since each point of difference shows different levels of development. 
Table 8. Results of vector $W_{P F}$ with FS-OWAAC operator

\begin{tabular}{cccccccccccccccccc}
\hline$w_{P F}$ & 1 & 2 & 3 & 4 & 5 & 6 & 7 & 8 & 9 & 10 & 11 & 12 & 13 & 14 & 15 & 16 & Ave \\
\hline $\mathrm{NB}_{1}$ & 0.00 & 3.18 & 4.55 & 6.88 & 6.88 & 7.11 & 7.28 & 7.90 & 9.61 & 9.61 & 10.1 & 10.2 & 10.5 & 10.5 & 11.0 & 11.4 & 7.91 \\
\hline $\mathrm{NB}_{2}$ & 0.00 & 3.12 & 4.46 & 6.74 & 6.74 & 6.96 & 7.13 & 7.74 & 9.41 & 9.41 & 9.92 & 9.97 & 10.3 & 10.3 & 10.8 & 11.1 & 7.75 \\
\hline $\mathrm{NB}_{3}$ & 0.00 & 3.06 & 4.38 & 6.62 & 6.62 & 6.84 & 7.00 & 7.61 & 9.25 & 9.25 & 9.74 & 9.79 & 10.1 & 10.1 & 10.6 & 10.9 & 7.62 \\
\hline $\mathrm{NB}_{4}$ & 0.00 & 2.83 & 4.04 & 6.11 & 6.11 & 6.31 & 6.46 & 7.02 & 8.53 & 8.53 & 8.99 & 9.04 & 9.29 & 9.34 & 9.75 & 10.1 & 7.03 \\
\hline $\mathrm{NB}_{5}$ & 0.00 & 2.73 & 3.90 & 5.91 & 5.91 & 6.10 & 6.25 & 6.78 & 8.25 & 8.25 & 8.69 & 8.74 & 8.98 & 9.03 & 9.42 & 9.76 & 6.79 \\
\hline $\mathrm{NB}_{6}$ & 0.00 & 2.99 & 4.27 & 6.46 & 6.46 & 6.67 & 6.83 & 7.42 & 9.02 & 9.02 & 9.50 & 9.56 & 9.82 & 9.88 & 10.3 & 10.6 & 7.43 \\
\hline
\end{tabular}

Table 9. Results of vector $W_{P F}$ with FS-OWAD operator

\begin{tabular}{cccccccccccccccccc}
\hline$w_{P F}$ & 1 & 2 & 3 & 4 & 5 & 6 & 7 & 8 & 9 & 10 & 11 & 12 & 13 & 14 & 15 & 16 & Ave \\
\hline $\mathrm{NB}_{1}$ & 0.00 & 0.85 & 1.21 & 1.83 & 1.83 & 1.89 & 1.94 & 2.10 & 2.56 & 2.56 & 2.69 & 2.71 & 2.78 & 2.80 & 2.92 & 3.02 & 2.10 \\
\hline $\mathrm{NB}_{2}$ & 0.00 & 1.09 & 1.55 & 2.35 & 2.35 & 2.42 & 2.48 & 2.70 & 3.28 & 3.28 & 3.45 & 3.47 & 3.57 & 3.59 & 3.74 & 3.88 & 2.70 \\
\hline $\mathrm{NB}_{3}$ & 0.00 & 0.98 & 1.41 & 2.13 & 2.13 & 2.20 & 2.25 & 2.44 & 2.97 & 2.97 & 3.13 & 3.15 & 3.23 & 3.25 & 3.39 & 3.51 & 2.45 \\
\hline $\mathrm{NB}_{4}$ & 0.00 & 1.28 & 1.82 & 2.76 & 2.76 & 2.85 & 2.92 & 3.17 & 3.85 & 3.85 & 4.06 & 4.08 & 4.19 & 4.21 & 4.40 & 4.56 & 3.17 \\
\hline $\mathrm{NB}_{5}$ & 0.00 & 1.49 & 2.13 & 3.23 & 3.23 & 3.33 & 3.41 & 3.70 & 4.50 & 4.50 & 4.74 & 4.77 & 4.90 & 4.93 & 5.14 & 5.33 & 3.71 \\
\hline $\mathrm{NB}_{6}$ & 0.00 & 1.11 & 1.59 & 2.41 & 2.41 & 2.49 & 2.55 & 2.77 & 3.36 & 3.36 & 3.54 & 3.56 & 3.66 & 3.68 & 3.84 & 3.98 & 2.77 \\
\hline
\end{tabular}

Table 10. Results of vector $W_{P F}$ with FS-OWAIMAM I operator

\begin{tabular}{cccccccccccccccccc}
\hline$w_{P F}$ & 1 & 2 & 3 & 4 & 5 & 6 & 7 & 8 & 9 & 10 & 11 & 12 & 13 & 14 & 15 & 16 & Ave \\
\hline $\mathrm{NB}_{1}$ & 0.00 & 0.22 & 0.32 & 0.49 & 0.49 & 0.50 & 0.51 & 0.56 & 0.68 & 0.68 & 0.71 & 0.72 & 0.74 & 0.74 & 0.77 & 0.80 & 0.56 \\
\hline $\mathrm{NB}_{2}$ & 0.00 & 0.27 & 0.39 & 0.59 & 0.59 & 0.61 & 0.62 & 0.67 & 0.82 & 0.82 & 0.86 & 0.87 & 0.89 & 0.90 & 0.93 & 0.97 & 0.67 \\
\hline $\mathrm{NB}_{3}$ & 0.00 & 0.33 & 0.47 & 0.71 & 0.71 & 0.73 & 0.75 & 0.81 & 0.99 & 0.99 & 1.04 & 1.04 & 1.07 & 1.08 & 1.13 & 1.17 & 0.81 \\
\hline $\mathrm{NB}_{4}$ & 0.00 & 0.66 & 0.95 & 1.44 & 1.44 & 1.48 & 1.52 & 1.65 & 2.01 & 2.01 & 2.11 & 2.12 & 2.18 & 2.20 & 2.29 & 2.37 & 1.65 \\
\hline $\mathrm{NB}_{5}$ & 0.00 & 0.64 & 0.91 & 1.38 & 1.38 & 1.42 & 1.45 & 1.58 & 1.92 & 1.92 & 2.02 & 2.03 & 2.09 & 2.10 & 2.19 & 2.27 & 1.58 \\
\hline $\mathrm{NB}_{6}$ & 0.00 & 0.41 & 0.58 & 0.88 & 0.88 & 0.91 & 0.94 & 1.02 & 1.23 & 1.23 & 1.30 & 1.31 & 1.34 & 1.35 & 1.41 & 1.46 & 1.02 \\
\hline
\end{tabular}

Table 11. Results of vector $W_{P F}$ with FS-OWAIMAM II operator

\begin{tabular}{cccccccccccccccccc}
\hline$w_{P F}$ & 1 & 2 & 3 & 4 & 5 & 6 & 7 & 8 & 9 & 10 & 11 & 12 & 13 & 14 & 15 & 16 & Ave \\
\hline $\mathrm{NB}_{1}$ & 0.00 & 0.46 & 0.66 & 1.00 & 1.00 & 1.04 & 1.06 & 1.15 & 1.40 & 1.40 & 1.48 & 1.48 & 1.52 & 1.53 & 1.60 & 1.66 & 1.15 \\
\hline $\mathrm{NB}_{2}$ & 0.00 & 0.21 & 0.30 & 0.45 & 0.45 & 0.46 & 0.47 & 0.51 & 0.63 & 0.63 & 0.66 & 0.66 & 0.68 & 0.69 & 0.71 & 0.74 & 0.52 \\
\hline $\mathrm{NB}_{3}$ & 0.00 & 0.47 & 0.67 & 1.02 & 1.02 & 1.05 & 1.08 & 1.17 & 1.42 & 1.42 & 1.50 & 1.51 & 1.55 & 1.56 & 1.62 & 1.68 & 1.17 \\
\hline $\mathrm{NB}_{4}$ & 0.00 & 0.50 & 0.71 & 1.08 & 1.08 & 1.11 & 1.14 & 1.24 & 1.51 & 1.51 & 1.59 & 1.60 & 1.64 & 1.65 & 1.72 & 1.78 & 1.24 \\
\hline $\mathrm{NB}_{5}$ & 0.00 & 0.59 & 0.85 & 1.28 & 1.28 & 1.32 & 1.36 & 1.47 & 1.79 & 1.79 & 1.89 & 1.90 & 1.95 & 1.96 & 2.04 & 2.12 & 1.47 \\
\hline $\mathrm{NB}_{6}$ & 0.00 & 0.47 & 0.67 & 1.01 & 1.01 & 1.04 & 1.07 & 1.16 & 1.41 & 1.41 & 1.49 & 1.50 & 1.54 & 1.55 & 1.61 & 1.67 & 1.16 \\
\hline
\end{tabular}

We have depicted results obtained in order to understand the behaviour of the information aggregated to specific industry (see Fig. 1). Illustration A shows the results of the FS-OWAAC operator, which are nearest of upper limit. They do not display significant differences between each alternative, even though alternatives $\mathrm{NB}_{1}, \mathrm{NB}_{2}$ and $\mathrm{NB}_{3}$ have more potential to be developed. Illustration $\mathrm{B}$ shows the results of the FS-OWAD, which are nearest of lower limit. They display significant differences between each alternative; 

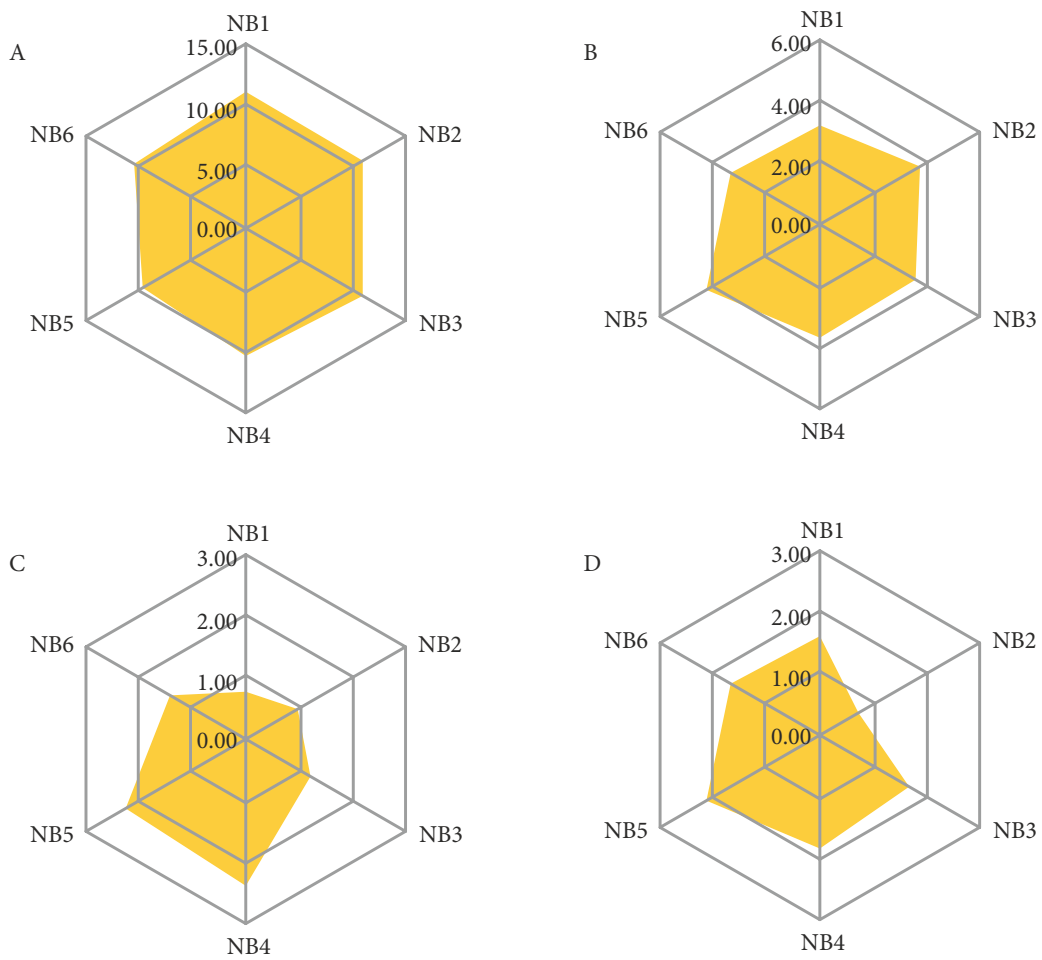

Fig. 1. Illustrated representation of each alternative

it is noteworthy that alternatives $\mathrm{NB}_{1}$ and $\mathrm{NB}_{3}$ can be developed with significance difference between other ones. Illustrations $\mathrm{C}$ and $\mathrm{D}$ show the results of the FS-OWAIMAM I and II, which are nearest of lower and upper limit simultaneously according to preferences of decision-maker. On the one hand, illustration $\mathrm{C}$ is noteworthy that the $\mathrm{NB}_{1}$ alternative is the most probable to be developed than other ones. On the other hand, illustration D is noteworthy that $\mathrm{NB}_{2}$ alternative is the most probable to develop than other ones.

Likewise, we can rank each alternative using the results obtained, which allows establishing order for all vectors (see Table 12). Since, we have used resulting data of current economic structure in Colombia, it is possible to analyse the individual decision-making and possibilities of development new business within the sports sector. It is to highlight that this methods are able to capture and deal with the environmental uncertainty and the subjectivity of the decision-maker. In this table, we show the order given for each method applied, the most favourable opportunities to be developed and their relationship with stage of development. Firstly, order has shown that the most favourable alternative to be carried out is $\mathrm{NB}_{1}$ followed by $\mathrm{NB}_{2}$. Likewise, order has shown also that alternatives $\mathrm{NB}_{3}$ and $\mathrm{NB}_{6}$ have great potential to develop an entrepreneurial initiative. Notwithstanding, environmental factors do not offer some necessary conditions to raise the possibility of development. Finally, in the last part of the order, we have found that alternatives $\mathrm{NB}_{4}$ and $\mathrm{NB}_{5}$ have limited opportunities to be developed because environmental factors are more 
hostile and less favourable. Secondly, we have classified each alternative according to the stage of development in order to determine the necessary stage to carry out some entrepreneurial alternatives proposed. Thus, the alternatives $\mathrm{NB}_{1}$ and $\mathrm{NB}_{2}$ are classified within the efficiency-stage and transition 2 of development. This stage is focused on promoting and helping to develop small businesses within the service economy. The alternatives $\mathrm{NB}_{3}$ and $\mathrm{NB}_{6}$ are classified in the transition 1 and efficient-stage of development. These kinds of industries are characterized by the development of scale economies, which are developed easily by large industries and incumbent firms since they have a dominant position on the market. Hence, current market conditions can affect the entrepreneurial activities positively or negatively, since they are focused on developing small-scale of manufactures and trade with the highest levels of self-employment. Finally, alternatives $\mathrm{NB}_{4}$ and $\mathrm{NB}_{5}$ need to develop high market sophistication. Currently, Colombia does not reach this level of development and sophistication, which impedes to encourage entrepreneurial activities with higher added valued within these kinds of industries. Thus, government's intervention becomes necessary to help reducing entrance barriers, fostering sports business with finance programs and promoting technological development and innovation within the sports sector.

Table 12. Matrix ordering of alternatives

\begin{tabular}{lcccccc}
\hline \multicolumn{1}{c}{ Order } & 1 & 2 & 3 & 4 & 5 & 6 \\
\hline FS-OWAAC & $\mathrm{NB}_{1}$ & $\mathrm{NB}_{2}$ & $\mathrm{NB}_{3}$ & $\mathrm{NB}_{6}$ & $\mathrm{NB}_{4}$ & $\mathrm{NB}_{5}$ \\
\hline FS-OWAD & $\mathrm{NB}_{1}$ & $\mathrm{NB}_{3}$ & $\mathrm{NB}_{2}$ & $\mathrm{NB}_{6}$ & $\mathrm{NB}_{4}$ & $\mathrm{NB}_{5}$ \\
\hline FS-OWAIMAM I & $\mathrm{NB}_{1}$ & $\mathrm{NB}_{2}$ & $\mathrm{NB}_{3}$ & $\mathrm{NB}_{6}$ & $\mathrm{NB}_{5}$ & $\mathrm{NB}_{4}$ \\
\hline FS-OWAIMAM II & $\mathrm{NB}_{2}$ & $\mathrm{NB}_{1}$ & $\mathrm{NB}_{6}$ & $\mathrm{NB}_{3}$ & $\mathrm{NB}_{4}$ & $\mathrm{NB}_{5}$ \\
\hline decision-making possibilities & the most favourable & some possibility & more difficult \\
\hline \multicolumn{1}{c}{ stage of development } & $\begin{array}{c}\text { Efficient-stage and } \\
\text { transition 2 }\end{array}$ & $\begin{array}{c}\text { Efficient-stage and } \\
\text { transition 1 }\end{array}$ & $\begin{array}{c}\text { Innovation stage and } \\
\text { transition 2 }\end{array}$ \\
\hline
\end{tabular}

Source: own elaboration.

\section{Conclusions}

In this paper, we have analysed three main items, the economic environment factors, individual decision-making processes and degree of uncertainty and subjectivity in order to determine the influence on decision-maker to start new businesses. Likewise, we have studied entrepreneurship from economic view, the factors that take into account the entrepreneur to make the decision to carry out an entrepreneurial activity or not, and its importance on the process of change towards knowledge-based economy. We have proposed a mathematical operator, which allow aggregating resulting data of the environmental factors and attitudinal character of decision-maker that represents the degree of subjectivity and the degree of uncertainty. Specifically, this new proposal allows aggregating information of an uncertain environment from the significance of its characteristics and developing a practical tool to select of the entrepreneurial opportunities according to a) the market and economic conditions within a specific country, b) attitude of potential entrepreneur and c) 
uncertainty generated by politic, economy and social changes. We have considered resulting data of the economic environment of Colombia and the sports sector as case study to carry out the application of the method proposed. The results have shown the possibility of development of each alternative according to variables studied. These results have shown also in an orderly way all information aggregated, which can help potential investors and entrepreneurs to make a decision based on their preferences. It is noteworthy that the results allow analysing each alternative according to the stage of development, which provided overview about the possibilities to start new business within the current market structure. Furthermore, this new extension of the OWA operator has several implications. Firstly, the results of the economy and social conditions obtained from local and global reports can be better interpreted using this new method. Secondly, objective and subjective information from different sources can be aggregated in the same formulation and obtained a representative value, which provide a holistic view of the specific environment. Thirdly, this new method allows dealing with uncertainty beyond the importance of the characteristics that has the information. Finally, the applicability of this method in real case can be given in aggregation different sources of information to help at dealing decision-making processes, either entrepreneurial activity context or formulation of new policies and programs for the industrial and social development.

\section{References}

Acs, Z. J.; Amorós, J. E. 2008. Entrepreneurship and competitiveness dynamics in Latin America, Small Business Economics 31(3): 305-322. https://doi.org/10.1007/s11187-008-9133-y

Amorós, J. E.; Bosma, N. 2014. Global Entrepreneurship Monitor 2013 Global Report [online], [cited 14 June 2014]. Santiago de Chile. Available from Internet: http://www.gemconsortium.org/assets/ uploads/1312480133GEM\{_\}2007\{_\}Executive\{_\}Report.pdf

Audretsch, D. B. 2009. The entrepreneurial society, The Journal of Technology Transfer 34(3): 245-254. https://doi.org/10.1007/s10961-008-9101-3

Audretsch, D. B.; Peña-Legazkue, I. 2012. Entrepreneurial activity and regional competitiveness: an introduction to the special issue, Small Business Economics 39(3): 531-537. https://doi.org/10.1007/s11187-011-9328-5

Audretsch, D. B.; Thurik, R. 2001. What's new about the new economy? Sources of growth in the managed and entrepreneurial economies, Industrial and Corporate Change 10(1): 267-315. https://doi.org/10.1093/icc/10.1.267

Audretsch, D.; Keilbach, M. 2004. Entrepreneurship capital and economic performance, Regional Studies 38(8): 949-959. https://doi.org/10.1080/0034340042000280956

Backhaus, J. G. 2003. Joseph Alois Schumpeter entrepreneurship, style and vision (1st ed.). New York: Kluwer Academic Publishers. https://doi.org/10.1007/b101851

Carree, M. A.; Thurik, A. R. 2010. The impact of entrepreneurship on economic growth, in Z. J. Acs, D. B. Audretsch (Eds.). Handbook of entrepreneurship research (5th ed.). New York, NY: Springer New York, pp. 557-594. https://doi.org/10.1007/978-1-4419-1191-9_20

CEC. 2012. Regional competitiveness in Colombia: Framework, findings and advices of the competitiviness and strategy centre 2012 [online], [cited 30 June 2012]. Competitivenss and strategy centre-competitiviness observatory. Available from internet: http://cec.uniandes.edu.co/images/pdf/articulo1. pdf. [In Spanish] 
Casero, J. C. D.; González, M. A.; Escobedo, M. de la C. S.; Martínez, A. C.; Mogollón, R. H. 2013. Institutional variables, entrepreneurial activity and economic development, Management Decision 51(2): 281-305. https://doi.org/10.1108/00251741311301821

Chandler, A.; Hikino, T. 1996. Scope and escale: dynamic of industrial capitalism, issue 1. Universidad de Zaragoza, Prensas Universitarias. (In Spanish)

Cuervo, A. 2005. Individual and environmental determinants of entrepreneurship, The International Entrepreneurship and Management Journal 1(3): 293-311. https://doi.org/10.1007/s11365-005-2591-7

Emrouznejad, A.; Marra, M., 2014. Ordered weighted averaging operators 1988-2014: a citation based literature survey, International Journal of Intelligent Systems 29(11): 994-1014. https://doi.org/10.1002/int.21673

GEM. 2008. Global entrepreneurship monitor 2007 executive report [online], [cited 14 June 2014]. Global Entrepreneurship Monitor. Available from Internet: http://gemconsortium.org/ assets/ uploads/1312480133GEM_2007_Executive_Report.pdf

GEM. 2014. Global entrepreneurship monitor 2013 global report [online], [cited 14 June 2014] Global Entrepreneurship Monitor. Available from Internet: http://gemconsortium.org/docs/3106/gem2013-global-report

GEM Colombia. 2014. Business dynamic in Colombia [online], [cited 16 August 2014]. Global Entrepreneurship Monitor Colombia. Available from Internet: http://gemconsortium.org/docs/download/3372. (In Spanish)

Gil-Aluja, J. 1999. Elements for a theory of decision in uncertainty. Dordrecht: Kluwer Academic Publishers. https://doi.org/10.1007/978-1-4757-3011-1

Gil-Lafuente, A. M.; Merigó, J. M. 2007. The ordered weighted averaging distance operator, Lectures on Modelling and Simulation 8(1): 84-95.

Gil-Lafuente, A. M.; Merigó, J. M. 2009. On the use of the OWA operator in the adequacy coefficient, Modelling, Measurement and Control D 30(1): 1-17.

Gil-Lafuente, J. 2001. Index of maximum and minimum level in the optimization of athlete signing. Proceeding of X Internacional Congress A.E.D.E.M, 439-443. (In Spanish)

Gil-Lafuente, J. 2002. Keys for success in sport management. Vigo: Ed. Malladoiro.

Hamming, R. W. 1950. Error detecting and error correcting codes, Bell System Technical Journal 29(2): 147-160. https://doi.org/10.1002/j.1538-7305.1950.tb00463.x

Heinemann, K. 1994. Sport as consumption, Apunts-Educacio Física i Esport, 37(3): 49-56. (In Spanish)

He, Y. D.; Chen, H. Y.; Zhou, L. G.; Liu, J. P.; Tao, Z. F. 2014. Intuitionistic fuzzy geometric interaction averaging operators and their application to multi-criteria decision-making, Information Sciences 259: 142-159. http://doi.org/10.1016/j.ins.2013.08.018

He, Y. D.; Chen, H. Y.; He, Z.; Zhou, L. G. 2015a. Multi-attribute decision making based on neutral averaging operators for intuitionistic fuzzy information, Applied Soft Computing 27: 64-76. https://doi.org/10.1016/j.asoc.2014.10.039

He, Y. D.; He, Z.; Chen, H. Y. 2015b. Intuitionistic fuzzy interaction Bonferroni means and its application to multiple attribute decision-making, IEEE Transactions on Cybernetics 45: 116-128. https://doi.org/10.1109/TCYB.2014.2320910

He, Y. D.; He, Z.; Wang, G.; Chen, H. 2015c. Hesitant fuzzy power Bonferroni means and their application to multiple attribute decision-making, IEEE Transactions on Fuzzy Systems 23(5): 1655-1668. https://doi.org/10.1109/TFUZZ.2014.2372074

Herrera, F. 1995. A sequential selection process in group decision making with a linguistic assessment approach, Information Sciences 85(4): 223-239. https://doi.org/10.1016/0020-0255(95)00025-K

Herrera, F.; Martinez, L. 2000. A 2-tuple fuzzy linguistic representation model for computing with words, IEEE Transactions on Fuzzy Systems 8(6): 746-752. https://doi.org/10.1109/91.890332

Kaufmann, A.; Gil-Aluja, J. 1986. Introduction of the fuzzy sub-sets theory to the business administration. Santiago de Compostela: Milladoiro. [In Spanish] 
Kaufmann, A.; Gil-Aluja, J. 1987. Management techniques for dealing with uncertainty. Barcelona: Hispano-Europea. [In Spanish]

Merigó, J. M. 2009. New extentions to the OWA operators and their applications in decision making: $\mathrm{PhD}$ thesis. University of Barcelona. [In Spanish]

Merigó, J. M. 2010. Fuzzy decision-making with immediate probabilities, Computers \& Industrial Engineering 58(4): 651-657. https://doi.org/10.1016/j.cie.2010.01.007

Merigó, J. M.; Gil-Lafuente, A. M. 2006. Using OWG operators in the selection of financial products, Lectures on Modelling and Simulation 7(3): 49-55.

Merigó, J. M.; Gil-Lafuente, A. M. 2008a. On the use of the OWA operator in the Euclidean distance, International Journal of Computer Science and Engineering 2(4): 170-176.

Merigó, J. M.; Gil-Lafuente, A. M. 2008b. The generalized adequacy coefficient and its application in strategic decision-making, Fuzzy Economic Review XIII(2): 17-36.

Merigó, J. M.; Gil-Lafuente, A. M. 2008c. Using the OWA operator in the Minkowski distance, International Journal of Computer Science 3: 147-157.

Merigó, J. M.; Gil-Lafuente, A. M. 2009. The induced generalized OWA operator, Information Sciences 179(6): 729-741. https://doi.org/10.1016/j.ins.2008.11.013

Merigó, J. M.; Gil-Lafuente, A. M. 2010. New decision-making techniques and their application in the selection of financial products, Information Sciences 180(11): 2085-2094. https://doi.org/10.1016/j.ins.2010.01.028

Merigó, J. M.; Gil-Lafuente, A. M. 2011. Decision-making in sport management based on the OWA operator, Expert Systems with Applications 38(8): 10408-10413.

https://doi.org/10.1016/j.eswa.2011.02.104

Merigó, J. M.; Gil-Lafuente, A. M. 2012a. A method for decision making with the OWA operator, Computer Science and Information Systems 9(1): 357-380. https://doi.org/10.2298/CSIS110206044M

Merigó, J. M.; Gil-Lafuente, A. M. 2012b. Decision-making techniques with similarity measures and OWA operators, SORT - Statistics and Operations Research Transactions 36(1): 81-102.

Merigó, J. M.; Gil-Lafuente, A. M. 2013. A method for decision-making based on generalized aggregation operators, International Journal of Intelligent Systems 28(5): 453-473. https://doi.org/10.1002/int.21585

Merigó, J. M.; Gil-Lafuente, A. M.; Gi-Aluja, J. 2011. A new aggregation method for strategic decisionmaking and its application in assignment theory, African Journal of Business Management 5(11): 4033-4043.

Merigó, J. M.; Gil-Lafuente, A. M.; Xu, Y. J. 2013. Decision-making with induced aggregation operators and the adequacy coefficient, Economic Computation and Economic Cybernetics Studies and Research (1): 185-202

Merigó, J. M.; Peris-Ortiz, M. 2014. Entrepreneurship and decision-making in Latin America, Innovar Journal of Administrative and Social Sciences 24(1Spe): 101-111. https://doi.org/10.15446/innovar.v24n1spe.47557

Merigó, J. M.; Peris-Ortiz, M.; Palacios-Marqué, D. 2014. Entrepreneurial fuzzy group decision-making under complex environments, Journal of Intelligent and Fuzzy Systems 27(2): 901-912.

Miller, T.; Kim, A. B.; Holmes, K. R. 2014. Index of economic freedom: promoting economic opportunity and prosperity by country. New York.

Peng, B.; Ye, C. 2014. An approach based on the induced uncertain pure linguistic hybrid harmonic averaging operator to group decision making, Economic Computation and Economic Cybernetics Studies and Research 47(4): 275-296.

Peng, D.-H.; Wang, T.-D.; Gao, C.-Y. 2014. Integrating nonhompgeneous preferences structures in SWOT analysis to evaluate multiple alternatives, Economic Computation and Economic Cybernetics Studies and Research 48(3): 309-332. 
Praag, C. M.; Versloot, P. H. 2007. What is the value of entrepreneurship? A review of recent research, Small Business Economics 29(4): 351-382. https://doi.org/10.1007/s11187-007-9074-X

Ratten, V.; Ratten, H. 2011. International sport marketing: practical and future research implications, Journal of Business \& Industrial Marketing 26(8): 614-620. https://doi.org/10.1108/08858621111179886

Sala i Martín, X.; Bilbao-Osorio, B.; Blanke, J.; Drzeniek, M.; Geiger, T.; Ko, C. 2014. Global competitiveness index: sustaining growth, building resilience. New York.

Shannon, C. E. 1948. A mathematical theory of communication, Bell System Technical Journal 27(3): 379-423. https://doi.org/10.1002/j.1538-7305.1948.tb01338.x

van Stel, A.; Carree, M.; Thurik, R. 2005. The effect of entrepreneurial activity on national economic growth, Small Business Economics 24(3): 311-321. https://doi.org/10.1007/s11187-005-1996-6

Verheul, I.; Wennekers, S.; Audretsch, D.; Thurik, R. 2002. An eclectic theory of entrepreneurship: Policies, instittutions and culture, Chapter 2 in D. Audretsch, R. Thurik, I. Verheul, S. Wennekers (Eds.). Entrepreneurship : determinants and policy in a european-US comparison. Boston: Kluwer Academic, 11-81. https://doi.org/10.1007/b109395

Wei, G. 2009. Uncertain linguistic hybrid geometric mean operator and its applications to group decision making under uncertain linguistic environment, International Journal of Uncertainty, Fuzziness and Knowledge-Based Systems 17(02): 251-267. https://doi.org/10.1142/S021848850900584X

Wei, G.; Lin, R.; Zhao, X.; Wang, H. 2014. An approach to multiple attribute decision making based on the induced Choquet integral with fuzzy number intuitionistic fuzzy information, Journal of Business Economics and Management 15(2): 277-298. https://doi.org/10.3846/16111699.2012.707984

Wennekers, S.; Thurik, R. 1999. Linking entrepreneurship and economic growth. Small Business Economics, 13(1): 27-56. https://doi.org/10.1023/A:1008063200484

Wennekers, S.; van Wennekers, A.; Thurik, R.; Reynolds, P. 2005. Nascent entrepreneurship and the level of economic development, Small Business Economics 24(3): 293-309. https://doi.org/10.1007/s11187-005-1994-8

Wong, P. K.; Ho, Y. P.; Autio, E. 2005. Entrepreneurship, innovation and economic growth: evidence from GEM data, Small Business Economics 24(3): 335-350. https://doi.org/10.1007/s11187-005-2000-1

WEF. 2002. The global competitiveness report 2001-2002 [online], [cited 16 August 2014]. World Economic Forum. Available from Internet: http://www.nectec.or.th/pld/indicators/documents/WEFGlobal Competitiveness Report 2001.pdf

WEF. 2014. The global competitiveness report 2013-2014 [online], [cited 16 August 2014] World Economic Forum. Available from Internet: http://www.weforum.org/reports/global-competitivenessreport-2013-2014.

Xu, Y.; Wang, H.; Merigó, J. M. 2014. Intuitionistic fuzzy Einstein Choquet integral operators for multiple attribute decision making, Technological and Economic Development of Economy 20(2): 227-253. https://doi.org/10.3846/20294913.2014.913273

Xu, Z. S. 2004. EOWA and EOWG operators for aggregating linguistic labels based on linguistic preference relations, International Journal of Uncertainty, Fuzziness and Knowledge-Based Systems 12(06): 791-810. https://doi.org/10.1142/S0218488504003211

Yager, R. R. 1988. On ordered weighted averaging aggregation operators in multicriteria decisionmaking, IEEE Transactions on Systems, Man, and Cybernetics 18(1): 183-190. https://doi.org/10.1109/21.87068

Yager, R. R. 1993. Families of OWA operators, Fuzzy Sets and Systems 59(2): 125-148. https://doi.org/10.1016/0165-0114(93)90194-M

Yager, R. R.; Kacprzyk, J. 1997. The ordered weighted averaging operators - theory and applications (1st ed.). New York: Kluwer Academic Publishers. https://doi.org/10.1007/978-1-4615-6123-1

Yager, R. R.; Kelman, A. 1999. An extension of the analytical hierarchy process using OWA operators, Journal of Intelligent \& Fuzzy Systems: Applications in Engineering and Technology 7(4): 401-417. 
Yager, R. R.; Kacprzyk, J.; Beliakov, G. 2011. Recent developments on the ordered weighted averaging operators: theory and practice. Berlin: Springer-Verlag.

Zhao, H.; Xu, Z.; Ni, M.; Liu, S. 2010. Generalized aggregation operators for intuitionistic fuzzy sets, International Journal of Intelligent Systems 25(1): 1-30. https://doi.org/10.1002/int.20386

Zhou, L.-G.; Chen, H. 2010. Generalized ordered weighted logarithm aggregation operators and their applications to group decision making, International Journal of Intelligent Systems 25(7): 683-707. https://doi.org/10.1002/int.20419

Zhou, L. G.; Tao, Z. F.; Chen, H. Y.; Liu, J. P. 2014. Intuitionistic fuzzy ordered weighted cosine similarity measure, Group Decision and Negotiation 23(4): 879-900. https://doi.org/10.1007/s10726-013-9359-1

Fabio BLANCO-MESA is a Professor in the School of Business Administration at the Pedagogical and Technological University of Colombia (Colombia). He has a two MSc and a PhD Degree in Business Administration from the University of Barcelona (Spain). He also holds a Bachelor from the District University Francisco José de Caldas. He has published several papers in international journals, books and conference proceedings such as Knowledge-Based Systems, International Journal of Intelligent Systems, Lecture Notes in Business Information Processing, Advances in Intelligent Systems and Computing, Studies in Fuzziness and Soft Computing, Journal Computational Optimization in Economics and Finance, Innovation in Service Firms: Perspective From Innovative Behaviour. He also serves as a reviewer for several international journals. He is currently interested in decision-making, entrepreneurship, competitiveness, fuzzy systems, aggregation operators, strategy, stakeholders, sport management and uncertainty.

Anna Maria GIL-LAFUENTE is a Professor in the Department of Business Administration at the University of Barcelona (Spain). She has a MSc and a PhD Degree in Business Administration from the University of Barcelona. She has published more than 450 papers in journals, books and conference proceedings including journals such as Information Sciences, International Journal of Intelligent Systems, Applied Soft Computing, International Journal of Uncertainty, Fuzziness and Knowledge-Based Systems and Expert Systems with Applications. She has published more than 20 books including 10 with Springer and 2 with World Scientific. She is Editor-in-Chief of Nova Sciences Collection Computational Intelligence in Engineering, Economics, and Management and co-editor-in-chief of 8 journals published by the Association for Modeling and Simulation in Enterprises (AMSE). She is on the editorial board of several journals and scientific committees. She has also served as a reviewer for many journals. She is currently interested in decision-making, aggregation operators, fuzzy systems, uncertainty and finance.

José M. MERIGÓ is a Professor at the Department of Management Control and Information Systems at the University of Chile. Previously, he was a Senior Research Fellow at the Manchester Business School, University of Manchester (UK) and an Assistant Professor in the Department of Business Administration at the University of Barcelona (Spain). He has a MSc and a PhD degree in Business Administration from University of Barcelona, Spain. He also holds a Bachelor Degree in Economics and a Master Degree in European Business Administration and Business Law from Lund University, Sweden. He has published more than 300 papers in journals, books and conference proceedings including journals such as Information Sciences, European Journal of Operational Research, Technological and Economic Development of Economy, Expert Systems with Applications, International Journal of Intelligent Systems and Computers \& Industrial Engineering. He has published 10 books including four with Springer and two with World Scientific. He is on the editorial board of several journals including the Journal of Business Research, Technological and Economic Development of Economy, Journal of Intelligent \& Fuzzy Systems and Economic Computation and Economic Cybernetics Studies and Research. He has participated in several scientific committees and serves as a reviewer in a wide range of journals. He is currently interested in aggregation operators, decision-making, uncertainty and bibliometrics. 